\title{
Obesity among parents and children from an indigenous rural community in Mexico
}

\author{
San Cristóbal Huichochitlán, Toluca, State of Mexico, Mexico
}

\section{DBESITY IN DEVELDPING CQUNTRIES}

Whereas the prevalence of obesity is increasing in both developed and developing countries, ${ }^{1}$ there are few data from rural and indigenous populations relating to cardiovascular disease and metabolic risk factors. ${ }^{2}$

We have explored the prevalence of overweight and obesity among parents and children of the predominant Otomí indigenous group in the community of San Cristóbal Huichochitlán Toluca, State of Mexico, Mexico, excluding pregnant women. Statistical analysis was done using the Statistical Package for Social Science (SPSS) software, version 10 (SPSS Inc., Chicago, United States).

This study included 56 individuals: 22 individuals over 18 years of age and 34 younger individuals. All their families (10) had very low incomes (less than 0.5 United States dollars per hour of work). Three mothers and one father were illiterate, one mother and five fathers had not completed primary school, while four mothers and two fathers had completed their primary school education and one mother and one father had also attended secondary school. The other two individuals over 18 years were not neither fathers nor mothers but teenagers. Although seven of the ten families had their own houses, only eight had electricity and four had municipal water.

Furthermore, this Mexican indigenous group has genetic homogeneity and overexpressed polymorphisms that are associated with complex diseases. ${ }^{3}$ Because of the high emigration rate, these characteristics constitute a health problem in both Mexico and also the United States.

Among the adults, the mean age, weight, height and body mass index $(\mathrm{BMI})$ were $32.63 \pm 8.84$ years, $63.59 \pm 8.93 \mathrm{~kg}$, $1.57 \pm 0.09 \mathrm{~m}$ and $25.79 \pm 3.1 \mathrm{~kg} / \mathrm{m}^{2}$ respectively. The BMI (weight in kilograms divided by the square of the height in meters) that was taken as the cutoff for obesity was $>28.0$ and $>27.0$ and $\mathrm{kg} / \mathrm{m}^{2}$ for men and women respectively, as suggested for a Mexican population. ${ }^{4}$ The mean systolic blood pressures were $125 \pm 7.07$ and $106.87 \pm 9.23 \mathrm{mmHg}$ and the mean diastolic blood pressures were $85 \pm 7$ and $66.25 \pm 11.57 \mathrm{mmHg}$, for men and women respectively. The prevalence of obesity among men and women over 18 years was $27.27 \%$ and $45.45 \%$ respectively. Among the fathers it was $33.33 \%$ and among the mothers it was $44.44 \%$, without statistically significant difference attributable to age (Mann-Whitney $\mathrm{U}$ test, $\mathrm{p}=0.387$ ).
Almost $100 \%$ of the adult females had a higher waist circumference than the cutoff value $(>80 \mathrm{~cm})$. We found one boy and one girl in the $95^{\text {th }}$ percentile of the weight-to-age table, and there were eight undernourished children. Our findings among the adults were similar to other studies. ${ }^{5}$ In fact, it was alarming that in $66.66 \%$ of the families at least one parent was obese, but surprisingly we did not find any hypertensive women. Other negative characteristics in this community were insufficiencies of fruit and vegetables in the diet and declining consumption of traditional foods such as rice and beans. In addition to the two children in the $95^{\text {th }}$ percentile mentioned above, the prevalence of stunting among individuals less than 18 years of age was $23.52 \%$.

The high prevalence of overweight and obesity in developing countries such as Mexico and their association with diseases such as type 2 diabetes mellitus, heart disease and cancer is likely to have made these pathological conditions a high-priority problem on the agenda of the Ministry of Health. Unfortunately, the nutritional deterioration has most likely been due to the recent increases in the prices of basic products such as milk, eggs and corn tortillas.

Finally, obesity prevention measures aimed towards children are needed urgently. We believe that the Mexican government should encourage body mass index monitoring during childhood, with subsequent interventions as necessary to prevent obesity and type 2 diabetes mellitus in adulthood, and also a scientifically based public school physical activity program.

AUTHOR INFDRMATIDN

Rámon Arrizabalaga-Amarelo, MD. Former Director and Emeritus Professor of the School of Medicine, Autonomous University of the State of Mexico (UAEMEX), Mexico. ( $t$ )

Hugo Mendieta-Zerón, MD, MSc. Internal Medicine. PhD Student at University of Santiago de Compostela, Spain, through Young Talents Program of the Autonomous University of the State of Mexico (UAEMEX), and National Science and Technology Council (CONACYT), Mexico.

Address for correspondence:

Hugo Mendieta-Zerón

Department of Physiology, School of Medicine, University of Santiago

de Compostela, Spain

Rua San Francisco, $s / n$,

15782 Santiago de Compostela, Spain

Tel. +34-659685663

E-mail:mezh_74@yahoo.com 
1. Brundtland GH. From the World Health Organization. Reducing risks to health, promoting healthy life. JAMA. 2002;288(16):1974.

2. Sánchez-Castillo CP, Lara JJ, Villa AR, et al. Unusually high prevalence rates of obesity in four Mexican rural communities. Eur J Clin Nutr. 2001;55(10):833-40

3. Montano Loza AJ, Ramirez Iglesias MT, Perez Diaz I, et al. Association of alcohol-metabolizing genes with alcoholism in a Mexican Indian (Otomi) population. Alcohol. 2006;39(2):73-9.
4. Corona Muñiz I, Camacho Hernández R, Escobedo de la Peña J. Obesidad, distribución central de la grasa corporal y cardiopatía isquémica en población mexicana. [Obesity, central body fat distribution and ischemic cardiopathy in the Mexican population]. Arch Inst Cardiol Mex. 1996;66(2):143-50.

5. Martins IS, Marinho SP. O potencial diagnóstico dos indicadores da obesidade centralizada. The potential of central obesity anthropometric indicators as diagnostic tools]. Rev Saude Publica. 2003;37(6):760-7.

REFERENCES

Sources of funding: Arrizabalaga-Amarelo Ramón. Conflict of interest: None

Date of first submission: February 2, 2007

Last received: November 7, 2007

Accepted: November 9, 2007 